\title{
INVESTIGAÇÃO EM LINGUÍSTICA FORENSE E CIBERCRIME: AS INTERFACES DOS ESTUDOS DE LINGUAGEM E DE DIREITO SOB O OLHAR DO PROFESSOR RUI SOUSA-SILVA
}

\begin{abstract}
Rui Sousa-Silva
Doutor em Linguística Aplicada pela Aston University (Birmingham, Reino Unido) Professor Auxiliar da Faculdade de Letras / Universidade do Porto (Portugal)
\end{abstract}

Entrevistado por:

Jordana Lenhardt

Doutoranda em Letras - Linguística - pela Universidade do Estado do Rio de Janeiro

jordana.uerj@gmail.com

Thallita Mayra Soares Fernandes Doutoranda em Letras - Teoria da Literatura e Literatura Comparada - pela Universidade do Estado do Rio de Janeiro (UERJ) thallitamsf@gmail.com

Thiago Wallace Rodrigues dos Santos Lopes Mestrando em Letras - Língua Portuguesa - pela Universidade do Estado do Rio de Janeiro (UERJ) thiagodossantos16@gmail.com

Rui Sousa-Silva é professor auxiliar da Faculdade de Letras e investigador do Centro de Linguística (CLUP) da Universidade do Porto, onde desenvolve atualmente a sua investigação em Linguística Forense e Cibercrime. É licenciado em Tradução e mestre em Tradução e Terminologia pela Faculdade de Letras da Universidade do Porto (FLUP) e doutor em Linguística Aplicada - Linguística Forense pela Aston University (Birmingham, Reino Unido), onde defendeu com máximo êxito a sua tese em Linguística Forense: Detecting Plagiarism in the Forensic Linguistics Turn. Nessa tese, investigou atitudes transculturais relativamente ao plágio e propôs uma abordagem à detecção de plágio translíngue. É, também, autor e coautor de vários artigos sobre análise de autoria (computacional) e coeditor, com o Professor Malcolm Coulthard, da revista internacional bilíngue Language and Law / Linguagem e Direito.

Em além-mar, do outro lado do Atlântico, gentilmente, o Professor Rui concedeu esta entrevista à Revista Palimpsesto via e-mail para falar de questões sobre as quais tem se debruçado academicamente no âmbito da Linguística Forense. Também é digno de menção que esta entrevista conta com versão em língua inglesa, concedida pelo professor Rui, a quem agradecemos. 


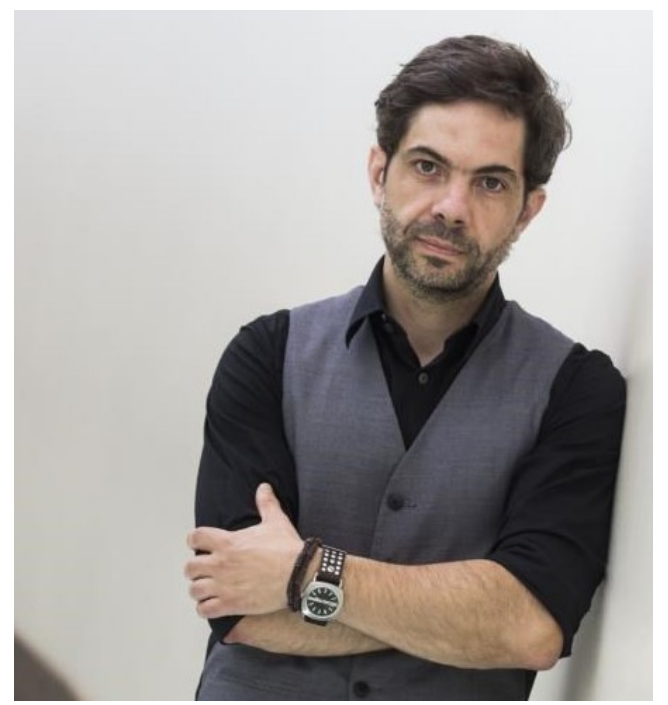

\section{PALIMPSESTO}

1) No âmbito dos estudos da linguagem, percebemos recentemente o despontar de uma nova área/disciplina - a Linguística Forense. Considerando-se que essa área atua nas interfaces entre a Linguagem e o Direito e seus atuais estudos nesse campo de pesquisa, o que despertou seu interesse na Linguística Forense?

\section{RUI SOUSA-SILVA}

Os estudos na área da linguística sempre foram do meu interesse, mas a possibilidade de recorrermos à análise linguística como forma de auxiliar a Justiça e contribuir, assim, para um mundo mais justo foi o meu principal interesse na área. Sempre me fascinou a capacidade de contribuir para um mundo melhor e, se isso puder ser feito através de uma área de que tanto gosto, como a linguística, tanto melhor. Nas minhas primeiras pesquisas sobre Linguística Forense, fiquei fascinado com o potencial da análise de autoria forense para descobrir os prováveis autores de textos anónimos e, assim, revelar criminosos. Curiosamente, bem antes de conhecer as aplicações da 
Linguística Forense, li um livro de um autor português que achei muito idêntico ao livro de um autor francês escrito no século XX. Fiquei intrigado e achei que poderíamos estar perante um caso de plágio. Nessa altura planeava fazer uma comparação entre os dois e verificar se esse plágio existia realmente. Então fiquei curioso com as capacidades de utilizar a análise da linguagem como forma de comprovar determinado caso como sendo plágio, ou o seu contrário - infirmar determinado caso como sendo plágio. Realço aqui esse aspeto, que é crucial: a análise linguística forense tanto pode contribuir para confirmar como para infirmar uma determinada suspeita, e as duas são igualmente importantes. Vejo muitas vezes estudantes muito interessados na área cujo enfoque é "apanhar criminosos". Não é esse o objetivo da Linguística Forense; eu diria que o principal compromisso da Linguística Forense é para com os Direitos Humanos. De qualquer modo, com uma gama tão alargada de áreas para desenvolver, acabou por ser essa a área do meu doutoramento em Linguística Forense: a deteção e análise de plágio.

\section{PALIMPSESTO}

2) Considerando-se o campo da análise linguística no contexto judicial, como atuam os Linguistas Forenses? Qual a formação necessária para atuar nessa área?

\section{RUI SOUSA-SILVA}

Não podemos esquecer-nos que a Linguística Forense é uma área verdadeiramente interdisciplinar, que assenta, sobretudo, na área da linguística, mas que recorre a conhecimentos de diversas outras áreas, como, em primeiro lugar, o Direito, mas também a Sociologia, a Comunicação, a Antropologia, a Estatística, a Informática, 
etc. Não obstante, temos que ter em consideração que o principal interesse da Linguística Forense é contribuir para assegurar uma administração adequada da Justiça. Por isso, para ser linguista forense e para atuar nessa área da linguística é necessário mais do que apenas formação em linguística. Poderemos ter uma formação excelente, aprofundada e altamente especializada numa subárea da linguística, mas isso não significa necessariamente ter competência para trabalhar como linguista forense. A Linguística Forense não é uma subárea da linguística, no sentido tradicional em que entendemos as subáreas da linguística (semântica, sintaxe, fonologia, pragmática, etc.); antes, é uma aplicação da linguística, na qual o linguista se baseia naquilo a que o Professor Malcolm Coulthard chamou de "caixa de ferramentas do linguista": o linguista forense dispõe de uma panóplia de ferramentas de análise linguística e as circunstâncias de cada caso irão determinar que ferramenta é que o linguista utilizará conforme o caso em análise. É por isso que é importante que o - ou a - linguista forense possua uma formação especializada na área, idealmente um doutoramento, pois é essa formação avançada que lhe permitirá ter os conhecimentos, a abertura, a capacidade de análise e a segurança adequadas. Não podemos esquecer que a análise linguística forense poderá ter impactos significativos na vida de outra pessoa, pelo que essa análise não é um mero exercício. Talvez como resultado da massificação das séries televisivas de ficção, o interesse pela Linguística Forense tem vindo a aumentar exponencialmente, e tenho visto diversas pessoas sem formação adequada a afirmar-se como Linguista Forense. Isso é uma irresponsabilidade. Não podemos esquecer-nos de que, em países como Portugal, a prova pericial está sujeita a requisitos legais e que qualquer negligência na prestação dessa prova pode implicar responsabilidade criminal para o próprio perito. Isso é sério. O trabalho de Linguista 
Forense é extremamente interessante, mas também extremamente exigente e pode ter sérias consequências legais.

\section{PALIMPSESTO}

3) Em sua opinião, quais as perspectivas para aqueles que se interessam em estudá-la?

\section{RUI SOUSA-SILVA}

A Linguística Forense tem no seu âmbito de aplicação imensas possibilidades, o que tem servido de campo a tanta pesquisa na área. Isso faz desta área um campo fértil para desenvolvimentos futuros, mas não podemos esquecer-nos de que a área ainda é relativamente recente e que, em países como Portugal, Brasil e muitos outros, as autoridades ainda não estão familiarizadas com todas as aplicações possíveis da área. Por isso, a área tem uma vantagem e uma desvantagem: a grande vantagem é que, de futuro, serão necessários mais linguistas forenses; a desvantagem é que não sabemos quando isso irá acontecer, pois, para que as autoridades competentes tenham ciência das capacidades da Linguística Forense, é necessário que os linguistas forenses continuem a fazer o seu trabalho, o que é difícil sem uma ligação às autoridades. É por esse motivo que, na maior parte dos casos, o trabalho de Linguista Forense tem sido um complemento ao trabalho académico, isto é, linguistas especializados em Linguística Forense que trabalham como professores e pesquisadores em Universidades.

\section{PALIMPSESTO}


Rui Sousa-Santos, Jordana Lenhardt, Thallyta Mayra S. Fernandes e Thiago Wallace R. S. Lopes

4) Qual o viés teórico para análise da linguagem em âmbito judicial?

\section{RUI SOUSA-SILVA}

Como referi anteriormente, na sua análise teórica e empírica é importante que o linguista forense recorra à sua "caixa de ferramentas": para cada caso concreto, o Linguista Forense escolhe, não só a ferramenta metodológica mais adequada, tendo em conta o caso que está a analisar, como também o enquadramento teórico adequado. Por exemplo, se eu estiver a trabalhar num caso de análise de autoria, interessam-me as teorias do idioleto; se estiver a trabalhar num caso de análise de significados, a teoria do idioleto não é relevante, sendo mais importante basear-me, por exemplo, em teorias de linguística de corpus, de semântica e de pragmática.

\section{PALIMPSESTO}

5) Além de professor da Faculdade de Letras e investigador do Centro de Linguística (CLUP) da Universidade do Porto, seus estudos também foram desenvolvidos na Europa. Qual sua relação com a área de Linguística Forense no Brasil? E qual sua visão dos estudos que vêm sendo desenvolvidos no país nessa área recentemente?

\section{RUI SOUSA-SILVA}

Desde 2012 que mantenho uma colaboração regular com o Brasil e tem sido um verdadeiro prazer ver a área a desenvolver-se dos dois lados do Atlântico. O meu doutoramento foi em Inglaterra, que, à data, era a melhor universidade do mundo para 
fazer doutoramento na área, e era onde estava situado o Centre for Forensic Linguistics (atualmente, Aston Institute for Forensic Linguistics) - e que continua a ser um Centro e uma Universidade de excelência. Isso não impediu que, apesar de eu estar a desenvolver o meu trabalho num contexto de língua inglesa, eu trabalhasse sobre a língua portuguesa. Não podemos esquecer que muitas das teorias e das metodologias que utilizamos em Linguística Forense são aplicáveis a diferentes línguas. Esse tem sido um trabalho interessante: aprofundar, transferir, ajustar, adaptar, desenvolver de novo muito do conhecimento que é disseminado em língua inglesa para a língua portuguesa. Não podemos esquecer também, naturalmente, que a língua portuguesa tem requisitos próprios, pelo que muito do trabalho que tenho vindo a desenvolver é exclusivo do português. É essa investigação/pesquisa que tenho vindo a partilhar com colegas no Brasil e que permite que a área venha a desenvolver-se mais robustamente nos dois países. E são também essas pontes entre o Portugal e o Brasil, e sobretudo entre a Universidade do Porto e a Universidade Federal de Santa Catarina (UFSC) - que culminaram no meu pós-doutoramento nas duas universidades -, que têm contribuído para um desenvolvimento mais aprofundado desses estudos.

\section{PALIMPSESTO}

6) O senhor ainda integra a ALIDI (Associação de Linguagem e Direito), que reúne pesquisadores, profissionais, estudantes e pessoas interessadas nos mais diversos e plurais estudos da Linguagem em suas interfaces com o Direito? Qual o papel dessa associação no cenário atual desses estudos? 


\section{RUI SOUSA-SILVA}

Já não sou integrante da ALIDI; desvinculei-me em 2018. Por isso, não serei a pessoa ideal para responder a essa pergunta. No entanto, integro a direção da IAFL International Association of Forensic Linguists, que é a associação internacional de linguistas forenses. A associação desenvolve atividades em todo o mundo, apoiando congressos, promovendo congressos regionais, organizando congressos internacionais bienalmente, e prestando apoio (muitas vezes financeiro) estudantes de doutoramento. Neste momento, estamos a continuar o trabalho de direções anteriores, já que o enfoque na qualidade e fiabilidade do trabalho realizado pelos linguistas forenses sempre foi um dos principais objetivos da IAFL.

\section{PALIMPSESTO}

7) Em parceria com o Professor Malcolm Coulthard, o senhor também edita e dirige a Revista "Language and Law / Linguagem e Direito" que conta com publicações de artigos tanto em língua inglesa como em língua portuguesa e com vieses bastante distintos de pesquisa. Em sua opinião, quais caminhos essas publicações indicam recentemente no mundo e no Brasil?

\section{RUI SOUSA-SILVA}

A publicação da revista Language and Law / Linguagem e Direito foi idealizada pelo Professor Malcolm Coulthard, que me convidou para integrar o projeto. Trata-se de uma revista extremamente importante, na medida em que é a única revista científica 
internacional que publica artigos também em português. Existe uma produção científica intensa em língua inglesa, mas a escassez de publicações em língua portuguesa é um problema, pois nem toda a gente interessada na área tem capacidade e recursos para aceder às publicações em língua inglesa. O objetivo da Language and Law / Linguagem e Direito é precisamente esse: fornecer um recurso de acesso livre, com publicações de qualidade, a todos aqueles que, pelos mais diversos motivos, não podem aceder a publicações em inglês. Isso implica um esforço enorme para a equipa editorial; porém, assume na íntegra esse objetivo de assegurar a disseminação da área em língua portuguesa, sem - realço - jamais descuidar a qualidade das publicações. Aliás, esse é o motivo pelo qual todos os artigos são revistos por dois pareceristas em formato anónimo, com vista a assegurar a qualidade das publicações aceites. Essa garantia de qualidade não existe em muitas das publicações atuais, que não passam por processos de revisão por pares.

\section{PALIMPSESTO}

8) Como Linguista Forense, seus estudos têm abordado a área de cibercrimes e detecção de plágio. Quais pesquisas o senhor está desenvolvendo no momento?

\section{RUI SOUSA-SILVA}

Neste momento, continuo a desenvolver estudos nessas áreas. A análise e deteção de plágio é uma área que continuo a considerar extremamente importante e que nunca está completamente desenvolvida; todos os dias, decorrente do desenvolvimento das tecnologias da informação e da comunicação, e da criatividade dos plagiadores (que 
Rui Sousa-Santos, Jordana Lenhardt, Thallyta Mayra S. Fernandes e Thiago Wallace R. S. Lopes

sempre inventam novas estratégias para plagiar), são desenvolvidas novas formas de plagiar, pelo que o trabalho de análise linguística forense é permanentemente necessário para identificar e prever essas estratégias. A outra área é o cibercrime. Com a massificação das comunicações eletrónicas e das redes sociais (media social), os utilizadores têm a perceção de que estão anónimos, escondidos por detrás de um ecrã, e isso leva a que julguem que podem cometer crimes de ódio, insultar, injuriar e ameaçar sem serem descobertos. Essa é, por isso, uma área extremamente relevante. Dentro desta área, estou neste momento a desenvolver pesquisa sobre deteção de fake news, na perspetiva da Linguística Forense. Espero ter publicações em breve. 


\title{
FORENSIC LINGUISTIC AND CYBERCRIME INVESTIGATION: STUDIES OF LANGUAGE AND LAW INTERFACES IN PROFESSOR RUI SOUSA- SILVA PERSPECTIVE
}

\begin{abstract}
Rui Sousa-Silva
Doctor in Applied Linguistics by Aston University (Birmingham, United Kingdom) Assistant professor of the Faculty of Arts and Humanities and researcher of the Linguistics Centre (CLUP) of the University of Porto

Interviewed by: Jordana Lenhardt PhD student in Letters - Linguistics (University of the State of Rio de Janeiro, UERJ) jordana.uerj@gmail.com

Thallita Mayra Soares Fernandes PhD student in Letters (University of the State of Rio de Janeiro, UERJ) thallitamsf@gmail.com

Thiago Wallace Rodrigues dos Santos Lopes Master's student in Letters - Portuguese Language (University of the State of Rio de Janeiro, UERJ) thiagodossantos16@gmail.com
\end{abstract}

Rui Sousa-Silva is assistant professor of the Faculty of Arts and Humanities and researcher of the Linguistics Centre (CLUP) of the University of Porto, where he conducts his research into Forensic Linguistics and cybercrime. He has a first degree in Translation and a Masters in Terminology and Translation, both awarded by the Faculty of Arts and Humanities of the University of Porto, and a PhD in Applied Linguistics - Forensic Linguistics, from Aston University (Birmingham, UK), where he submitted his thesis on Forensic Linguistics: 'Detecting Plagiarism in the Forensic Linguistics Turn.' He studied cross-cultural attitudes to plagiarism, and proposed an approach to translingual plagiarism detection. He also authored and co-authored several papers on (computational) authorship analysis, and is co-editor with Professor Malcolm Coulthard, of the international bilingual journal Language and Law / Linguagem e Direito.

From across the Atlantic, Dr. Rui Sousa-Silva kindly accepted to give an interview to Palimpsesto by e-mail, where he discusses the research he has been conducting in the field of Forensic Linguistics. This interview has also a version in English, which has also been answered in the language by Professor Rui, to whom this journal thanks. 


\section{PALIMPSESTO}

1) Within the scope of language sciences, a new field/discipline has recently emerged Forensic Linguistics. Since this is a field that focuses on the intersection between Language and the Law, and given your current research in the field, what drew your attention to Forensic Linguistics?

\section{RUI SOUSA-SILVA}

I have always been interested in language sciences and linguistics, but the possibility of using linguistic analysis to assist the administration of justice and thus contribute to a more just world really triggered my interest. I've always been fascinated by the prospects of contributing to a better world, and if I can do so by conducting my research in an area that I like so much, as is the case of linguistics, that is fantastic. In my earlier research in Forensic Linguistics I was thrilled by the potential of forensic linguistic analyses to reveal the most likely authors of anonymous texts, and thereby identify possible criminals. Interestingly, a few years before I got acquainted with the applications of Forensic Linguistics, I read a book written by a Portuguese author that I found particularly similar to a book written by a $20^{\text {th }}$ century French author. I found it intriguing and thought that this could be a case of plagiarism. I then planned on establishing a comparison between the two and ascertain if that was really an instance of plagiarism. So, I was curious about the possibility of using linguistic analysis to prove - or otherwise, reject - the hypothesis that a certain instance is a case of plagiarism. I'd like to highlight this feature, which is crucial: forensic linguistic analyses can both help confirm or reject a certain suspicion, and the two are equally important. I often meet students who are 
deeply interested in the area, and whose main focus is to 'help catch criminals.' That is not the aim of Forensic Linguistics; I'd rather argue that Forensic Linguistics is mainly committed to Human Rights. Anyway, given such a wide range of research possibilities in Forensic Linguistics, eventually I chose forensic linguistic analysis and detection of plagiarism as my PhD topic.

\section{PALIMPSESTO}

2) When one takes into account linguistic analysis in the judicial context, how do Forensic Linguists act? What sort of training is required to work in this area?

\section{RUI SOUSA-SILVA}

We must not forget that Forensic Linguistics is a truly interdisciplinary area, which builds mainly upon linguistics, but while also drawing on knowledge from several other areas, not only law, but also sociology, communication, anthropology, statistics, computer science, etc. Nevertheless, we have to bear in mind that the main interest of Forensic Linguistics is to contribute to ensuring an adequate administration of Justice. Therefore, to be a forensic linguist and to work in this area of linguistics, more than just linguistic training is required. One can have excellent, in-depth and highly specialised training in a sub-area of linguistics, but that does not necessarily mean that one has the competence to work as a forensic linguist. Forensic Linguistics is not a sub-area of linguistics on the same grounds as semantics, syntax, phonology, pragmatics, etc.; rather, it is an application of linguistics, where the linguist relies on what Professor Malcolm Coulthard calls the "linguist's toolbox": the forensic linguist has a range of tools for 
linguistic analyses and the circumstances of each case will determine which tools the linguist will use, according to the specificities of that case. That's why it is so important that the forensic linguist has specialised training in the area, ideally a $\mathrm{PhD}$, as such advanced training will allow him/her to have the appropriate knowledge, openness, analysis and confidence skills. We must bear in mind that forensic linguistic analyses can have a significant impact on someone else's life, so those analyses are not just an exercise. Perhaps as a result of the widespread broadcast of fictional television series, interest in Forensic Linguistics has increased exponentially, and I have seen several people without adequate training claiming to be Forensic Linguists. This is an irresponsible behaviour. It is important to be aware that, in countries like Portugal, giving expert evidence must follow legal requirements, and the expert may be criminally liable for any act of negligence in giving such evidence. This is very serious. The work of a Forensic Linguist is extremely interesting, but also extremely demanding, and can have serious legal implications.

\section{PALIMPSESTO}

3) What do you think are the prospects for those who are interested in studying Forensic Linguistics?

\section{RUI SOUSA-SILVA}

Forensic Linguistics offers a wide range of research possibilities, and this has opened up the fields of research in the area. As a result, this area has become a fertile ground for future developments, although we need to take into account that the field is 
still relatively recent and that, in countries like Portugal, Brazil and many others, the legal institutions are not always familiar with all possible applications. This is why the field offers both an advantage and a disadvantage at the same time: the great advantage is that, in the future, more forensic linguists will be needed; the disadvantage is that we don't know, yet, when exactly this move will happen, because for the competent authorities to be aware of the possibilities offered by Forensic Linguistics, it is necessary for forensic linguists to carry on with their job, which is difficult when the link to the authorities is missing. This is why the work of Forensic Linguists has so frequently been complementary to academic work, so linguists specialised in Forensic Linguistics tend to work as professors and researchers at Universities.

\section{PALIMPSESTO}

4) What is the theoretical framework of linguistic analysis in legal contexts?

\section{RUI SOUSA-SILVA}

As I mentioned earlier, when approaching forensic cases, theoretically and empirically, it is crucial that the forensic linguist uses this 'linguist's toolbox': for each specific case, the forensic linguist must choose, not only the most appropriate methodological tool, taking into account the specific case in point, but also the most appropriate theoretical framework. For example, when working on an authorship analysis case, it is crucial to take into account the theory of idiolect; when working on a case of disputed meanings, using the theory of idiolect is less relevant than corpus linguistics theories, or principles of semantics and pragmatics. 


\section{PALIMPSESTO}

5) Although you are currently professor at the Faculty of Arts and Humanities and researcher at the Linguistics Centre (CLUP) of the University of Porto, you furthered your studies in Europe. To what extent are you involved in Forensic Linguistics in Brazil? Also, what do you think about the studies that have been conducted in the country recently?

\section{RUI SOUSA-SILVA}

I've collaborated with Brazil on a regular basis since 2012, and it has been a real pleasure to see the area growing on both sides of the Atlantic. I did my PhD in England, in the best University - and with the best team - in the world in the area at the time. This is where the Centre for Forensic Linguistics (currently Aston Institute for Forensic Linguistics) is located - both the Centre and the University remain institutions of excellence. The fact that I conducted my research in an English-speaking country did not prevent me from conducting my research into Portuguese. In fact, many of the theories and methodologies used in Forensic Linguistics apply to different languages, so this has been an exciting job: furthering, transferring, adjusting, adapting, and re-vamping to Portuguese a significant part of the knowledge that is disseminated in English. Of course, we must be aware that Portuguese has its own requirements, so a lot of the research that I've been conducting is exclusive to Portuguese. It is this research that I've been sharing with colleagues in Brazil, and which allows the field to develop more robustly in both countries. Moreover, these bridges between Portugal and Brazil, and especially between the University of Porto and the Federal University of Santa Catarina (UFSC) - which led to 
my postdoctoral research at both universities - have contributed to further develop this research.

\section{PALIMPSESTO}

6) You are still a member of ALIDI (Associação de Linguagem e Direito), which gathers researchers, practitioners, students and those with an interest in the interface between language and the law. What is the role of this association in the current research settings?

\section{RUI SOUSA-SILVA}

I am no longer a member of ALIDI, as I left in 2018. Therefore, I'm not the right person to answer this question. However, I am a Board member of the IAFL International Association of Forensic Linguists. The association promotes activities all over the world, including international and regional conferences, workshops, meetings, and supports (often financially) PhD students. The current Board is continuing the work of previous boards, because ensuring the quality and reliability of the work done by forensic linguists has always been one of the main objectives of the IAFL.

\section{PALIMPSESTO}

7) Together with Professor Malcolm Coulthard, you also edit the journal "Language and Law / Linguagem e Direito", which has articles published in both English and Portuguese 
Rui Sousa-Santos, Jordana Lenhardt, Thallyta Mayra S. Fernandes e Thiago Wallace R. S. Lopes

and with very different research lines. In your opinion, which directions have these publications recently pointed to in the world and in Brazil?

\section{RUI SOUSA-SILVA}

The journal Language and Law / Linguagem e Direito was initially planned by Professor Malcolm Coulthard, who invited me to join him as editor. It is an extremely important journal, as it is the only international scientific journal that publishes articles also in Portuguese. There is an intensive scientific production in English, but the scarcity of publications in Portuguese is an issue, because not everyone interested in the area has the possibility and resources to access publications in English. One of the aims of Language and Law / Linguagem e Direito is to address precisely this issue, by offering all those who, for diverse reasons, cannot access publications in English a free, open-access resource featuring quality articles in Portuguese. Of course, this demands a strong effort from the editorial team; however, the journal is fully committed to the objective of ensuring the dissemination of the field in Portuguese, without ever neglecting the quality of the articles that it publishes. In fact, this is the reason why all articles are double blind peer-reviewed, so as to ensure the quality of the manuscripts accepted for publication. This quality assurance procedure is not employed by all publications, so in most cases manuscripts don't even go through fair peer-review processes.

\section{PALIMPSESTO}

8) Your research into Forensic Linguists has approached the topic of cybercrime and plagiarism detection. What is your current line of research? 


\section{RUI SOUSA-SILVA}

I'm currently furthering my research in these areas. The analysis and detection of plagiarism is an area that I consider ever more important and that is never fully accomplished; every day, owing to the development of information and communication technologies, together with the creativity of plagiarists (who always invent new strategies to plagiarise), new forms of plagiarism are developed, so the work of forensic linguistic analysis is permanently necessary to identify and predict those strategies. The other area is cybercrime. With the massification of electronic communications and social media, users have the perception that they are anonymous, hidden behind a screen, and this leads them into believing that they can commit hate crimes, disseminate insults, and threaten without being identified. This is, therefore, an extremely relevant area. Within this area, I am currently developing research in fake news detection, from the perspective of Forensic Linguistics. I will publish more on this soon. 